\title{
Impact of Problem-based Learning in Developing Logical and Analytical Skills of Undergraduates
}

\author{
J.T. Weeraratna* \\ Department of Languages, General Sir John Kotelawala Defence University, Sri Lanka
}

\begin{abstract}
Problem-based Learning (PBL) is an influential and innovative method in language learning, where the real-life situations and issues of the learners are used as 'problem situations' in developing many other skills. Despite Sri Lanka marks a high literacy rate in Asia, it lies behind the average values of IQ abilities. Even though the country offers free education, it is observed that the competitive education system doesn't encourage its learners to develop their cognitive abilities and other soft skills. This research was aimed to find out the effectiveness of PBL in enhancing logical and analytical thinking skills. Its objectives were to study the influence of PBL in language education and to find out if logical and analytical thinking abilities be enhanced through PBL. The hypothesis was logical and analytical thinking abilities of the undergraduates can be developed through PBL. The research got a mixed-method approach. The target population consisted of 60 randomly selected undergraduates of a Sri Lankan University. A special module prepared by the researcher, based on developing cognitive skills of the undergraduates was tested on the population. A pre and a post 'spot-test' on critical thinking was given and the answers were individually compared and analyzed to see the impact. Randomly selected $1 / 4$ of the target group was interviewed to get the student perspective of PBL. It was noted that the thinking patterns of the students have developed; proving the capacity of PBL in developing thinking patterns in a positive way. It was confirmed that not only the analytical and logical thinking abilities, but also other cognitive skills such as critical thinking, justification skills as well as language skills could be developed through PBL.
\end{abstract}

Keywords: Problem-based Learning, Logical thinking, Analytical thinking, Cognitive skills

\section{Introduction}

Problem-based Learning (PBL) is an influential and innovative method in language learning which initiated with medical and clinical studies in 1960's. "In PBL, students learn by solving problems and reflecting on their experiences" (Barrows \& Tamblyn, 1980, p. 2). The real-life situations and issues of the learners are used as 'problem situations' and are used as the modes of developing many skills including logical and analytical thinking skills of the learners. According to Cindy \& Silver (2004), "Educators are interested in PBL because of its emphasis on active, transferable learning and its potential for motivating students" (p. 236).

Sri Lanka has a literacy rate of $92 \%$, marking the highest in South Asia. According to the ministry of Higher education of Sri Lanka, it is higher than the expected rate for a third world country. Yet the IQ level of Sri Lanka is $79^{1}$. The average level according to the international standards should be 90-110. Since it lies behind the average values, it is the responsibility of the individual to develop IQ standards to rise as a nation which is stable in intelligence.

Education is free in Sri Lanka and it falls under the control of both the Central Government and the Provincial Councils. Even though education is free, it is remarkably competitive as a limited number of students get the opportunity to enter the 15 state universities to follow free tertiary education which marks the standard of higher education in the country. The majority of undergraduates in state universities find difficulties to follow their respective degrees due to language barrier. Most of the students follow secondary education in their mother

${ }^{1}$ www.brainmetrics.com 
tongue, but since the medium of higher education is English, many of them find difficulties when continuing university education. As a result, they become subject oriented and focus so much on academic success; while the development of other soft skills gets ignored. On the other hand, when such graduates enter the job market of Sri Lanka, they often get blamed by the top hierarchy that they lack skills such as logical thinking, independent thinking, analytical thinking, IQ etc. According to ministry of higher education ${ }^{2}$, actions have been taken to enhance the demand in the job market value for local graduates by channeling them towards job oriented education system and providing them with effective communication skills and literacy in Information Technology. This strategy will ultimately improve the net value of the Human Capital in Sri Lanka.

Thus this research aims to find out the effectiveness of PBL in enhancing logical and analytical thinking skills. Its objectives are to study the influence of PBL in language education and to find out if logical and analytical thinking abilities can be enhanced through PBL. The hypothesis was logical and analytical thinking abilities of the undergraduates can be developed through PBL.

\section{Literature Review}

\section{ELT in Sri Lanka}

According to Ngowananchai (2013), "English is not limited to native speakers; it is also used for communication among non-native speakers" (p. 397). English was replaced by Sinhala (the main language of Sri Lanka), as the official language through Act no 33 of 1956. Later on giving equal importance to the minority of the country, in 1987, through Act no 13, Tamil was also named as an official language. Since then, according to the Department of Official Languages of Sri Lanka, Sinhala and Tamil languages are both Official and National Languages in Sri Lanka while English is the 'Link Language'.

Even though English plays a fundamental role in the education system of the country, according to Gunawardana \& Karunarathna (2017), ELT in Sri Lanka is considered a failure due to several reasons. "Out of several reasons it is apparent that teachers' skills, professional knowledge, perceptions and pedagogic practice contribute to the failure in ELT" (p1). Their suggestions imply that by making the teachers constantly aware of research on ELT and by supporting and uplifting their professionalism in ELT, the negative impact could be minimized. "Motivating teachers to engage in research would make teaching an evidence-based profession, making English language teaching and learning in Sri Lanka a success" (Karunarathna \& Gunawardana, 2017, p 2).

Sri Lankan government has implemented many training programmes to uplift teacher education related to English language teaching. Research show that for the teachers to develop constantly they should get the chance of experimenting new teaching methods together with continuous support and feedback from authorities. They should be given a continuous professional development so that they will be able to improve their skills and keep updated in their specific field. Exploring new dimensions of ELT in Sri Lanka, Attanayake (2010) suggests that a 'narrative-based curriculum' would encourage the learners by motivating them to engage in language learning because it makes them feel comfortable and the language becomes 'less-strange and less-challenged' for the learners.

\section{PBL, as a learning model in language education}

Learning models are important as they encourage and facilitate learning and provide guidance as to how it should happen. Since "PBL is well supported by learning theory" (Clayton \& Pierpoint, 1996, p2), it possesses a firm substance as a learning model in language learning. Among many definitions of PBL, the classification by

\footnotetext{
${ }^{2}$ http://www.mohe.gov.lk
} 
Hoffman \& Richie (1997), "Problem based learning is a student-centered pedagogical strategy that poses significant, contextualized, real-world, ill-structured situations while providing resources, guidance, instruction, and opportunities for reflection to learners as they develop content knowledge and problem-solving skills" (p 97) is outstanding. Many researches have graded PBL to be a learning method which has $100 \%$ student satisfaction. It is identified as a method of retaining memory by Lam (2004). Traditional teaching normally does not motivate students to question their knowledge, but PBL allows the learner to be vigilant on what they learn and be inquisitive on their existing knowledge. "Problem-based learning is seen as an innovative measure to encourage students to 'learn how to learn' via 'real-life' problems”' Boud \& Feletti (1999 as cited in Mai and Ken, 2001).

There are many soft skills as well as language skills that could be developed through PBL. Analytical thinking and logical thinking are two such skills that get developed through problem-based learning. Exploring EFL learners in Saudi Arabia, Kassem (2018) denote that "teacher-centered instruction is now admitted to lead to poor language performance" ( $p$ 134). He also mentions that a significant impact of motivation is found for student-centered instruction. English "is now a prerequisite for participation in a vast number of activities. The global village is being constructed in the English language, as are the information highways [and] access to findings in science and technology is made through English" (Modiano, 2001, p. 341).

Even though PBL is a very effective method in language teaching, it is viewed skeptically by many traditional teachers. Such teachers are "reluctant to implement it because of the tremendous amount of work involved in fundamentally restructuring a course" (Larsson, 2001, p 2). Since a language is a 'tool' of learning, and not an actual subject, language learning should be different than learning any other subject. Thus in language learning, "understanding is of course paramount - it is what languages are about" (Larsson, 2001, p 3). Therefore the teachers as well as the students should understand the challenge of acquiring the tool of learning any other subject and be flexible in adjusting to the novel and effective methods of language learning rather than adhering to one method which has been in use for years.

\section{Advantages and disadvantages of $P B L$}

According to Larsson (2001), through TBL, communicative skills and social interaction of the language learners get positively improved. Many of the language learners try to by-heart the vocabulary they need to pass the exam. Learners rarely try to focus on acquiring vocabulary and they often forget what they by-hearted after the exam. This 'superficial learning' is proven false by PBL as it gives learners a sense of acquisition for a longterm memory other than learning for exam purposes. PBL allows learners to experience the language in realworld situations rather than memorizing the language rules. "The feeling of being an integral part of their group also motivates students to learn in a way that the prospect of a final examination rarely manages to do" (Larsson, 2001, p 4). But research point out that lack of research in PBL, task of constructing suitable problem situations, relating novel and good concepts tally the previous knowledge of learners, finding a plausible context for problems and maintaining enthusiasm of the students towards the given task by making it challenging mark the disadvantages in PBL. Yet through understanding the learner needs and by relating the learning process to their own real-life situations, the facilitators can make PBL a pleasant and effective learning experience, making the disadvantages less prominent.

\section{Methodology}

The research took a mixed method approach. The target population consisted of 60 first year undergraduates of the Faculty of Engineering (FOE) at a Sri Lankan University. The sample was randomly selected. The students were grouped according to their stream of studies. The population consisted of undergraduates from Electrical and Electronic Engineering (EE), Marine Engineering (MR), Aeronautical Engineering (AE) and Air Craft 
Maintenance Engineering (ACM). The research was conducted throughout an academic semester, which consisted 15 weeks. A total number of 30 contact hours ( 2 contact hours per week) was covered.

A special module prepared by the researcher, who is an English language lecturer for the FOE, was tested on the target population (Appendix; table 01). The module was based on developing cognitive skills of the undergraduates. Every lesson was designed based on problem-based learning. They were centered on exploring problems and were thematically woven around a particular problem/s and were given 06 themes, which were derived from basics of PBL.

The themes (i) understanding a problem (ii) Identifying key issues of a problem (iii) analyzing a problem (iv) generating possible explanations (v) integrating new concepts and (vi) taking decisions and solving problems were designed in a way that by the end of PBL lessons, the students cover a vast area of problem solving; starting from understanding a problem to solving it. The four language skills; reading, writing, speaking and listening were also covered through the progression of lessons. The activities were designed in a manner that language skills were to be developed without any traditional teaching done on the board.

A mini spot-test on attitude was given on the 1st day of the skill development session. The same questions were posed on them at the last day. The answers were individually compared and analyzed in order to see if there is any impact on analytical and logical thinking abilities of the undergraduates as a result of their exposure to PBL. The 09 scale descriptors used in California Critical Thinking Skills Test (CCTST) were considered when analyzing the answers given by the undergraduates. As a widely used reliable test scale to measure the thinking abilities of undergraduates and graduates, CCTST describes strengths and weaknesses in various skills. The 09 descriptors used in CCTST are; reasoning skills, analysis, interpretation, inference, evaluation, explanation, deduction, induction and numeracy.

Out of these descriptors, reasoning skills, analysis, inference and explanation were specifically used as the key components of analyzing thinking skills of the target group.

The 4 questions given in the spot-test were as follows;

1. When crossing the road, Kasun looked only to the left. Why? ${ }^{3}$

2. Ann got 30 marks for the written test last semester. Usually she does not speak in English with her friends and teachers. However, this time she obtained 55 marks for writing. How do you think Ann improved her marks? ${ }^{4}$

3. You are going home in the evening. All of a sudden you notice your house is on fire. Your father, mother, grandmother and sister are inside. Unfortunately you can save only one person. Whom would you save? ${ }^{5}$

4. You are riding your motor-bicycle. It is about to rain. You see 3 people in a bus halt. One is an old man who is very sick (he is shivering and needs to be rushed into a hospital soon). The other one is your old friend who has helped you in various ways in the past (you have been waiting for a chance

\footnotetext{
${ }^{3}$ Critical/Analytical thinking development-2017/English Language Teaching Unit/University of Colombo

${ }^{4}$ Critical/Analytical thinking development-2017/English Language Teaching Unit/University of Colombo

${ }^{5}$ www.quora.com
} 
to help him). The third is your dream girl, your crush and the one you have been waiting to impress and ask out. What will you do now? Whom would you pick and offer to help?

These pre and post questions helped to find if there was any impact in making the students exposed to problembased learning.

10 students of the target group were interviewed to get the student perspective of Problem-based learning. The students were randomly selected from the main population. Their answers were analyzed using Qualitative Content Analysis. ${ }^{7}$

\section{Results \& Discussion}

In the pre attempt of the $1^{\text {st }}$ question, everybody has told Kasun looked only to the left because it was a one way road. But in the post attempt, the students have given 8 options. 51 said it was a one way road, 2 said that there must have been an accident on right and he needed to avoid that side as he was sensitive over accidents. One student said that Kasun's girlfriend's mother had been walking towards him, and he looked towards left to avoid her. Another student said Kasun is a careless guy who forgets to look both sides of a road when crossing. One student said that Kasun was observing/ responding to the horn of a vehicle and another student said that he was wearing a neck brace and it was difficult for him to turn his neck towards right.

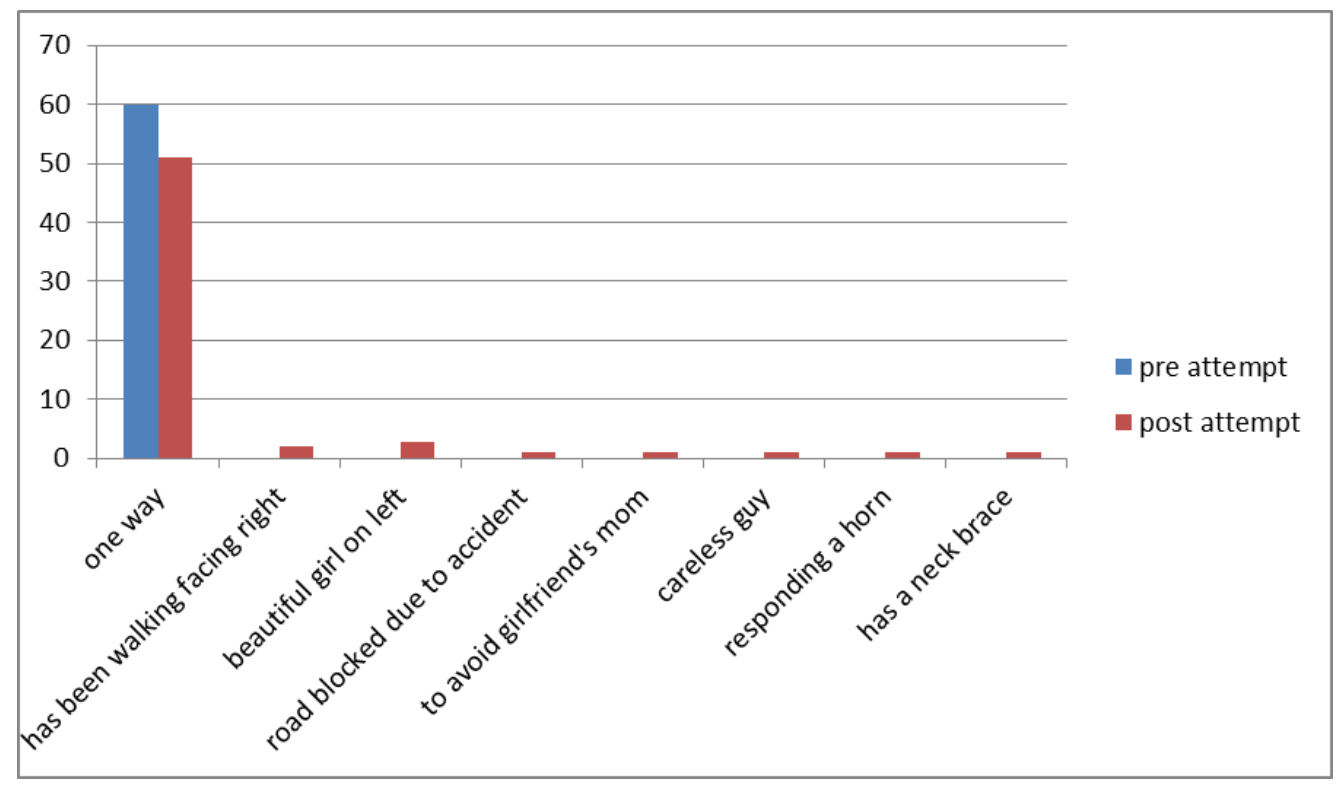

Figure 1: Evaluation of Question number 01

Here, it is obvious that the thinking patterns have developed by the time they wrote the post spot test. It is outstanding to note that even though there was only one option given at the pre spot-test, students have diversified their thoughts towards 8 options by the post spot-test.

For question 02, focusing on Ann improving English writing proficiency, 51 students in the pre attempt said she has done self-studies and 9 students said she has watched movies to improve. But in post attempt, 20 students

\footnotetext{
${ }^{6}$ www.alvinalexander.com

7 Approach of empirical, methodological controlled analysis of texts within their context of communication, following content analytical rules.
} 
said it was through self-studies, 12 said it was after working on past papers, 17 said, it was after reading English books, novels and newspapers, 5 said she has copied, 1 said her identical twin wrote the paper, 3 said after watching movies and 2 said that she has improved her written skills after starting a relationship with a guy who is good in the language and have argued that it was her boyfriend's influence which made her improve.

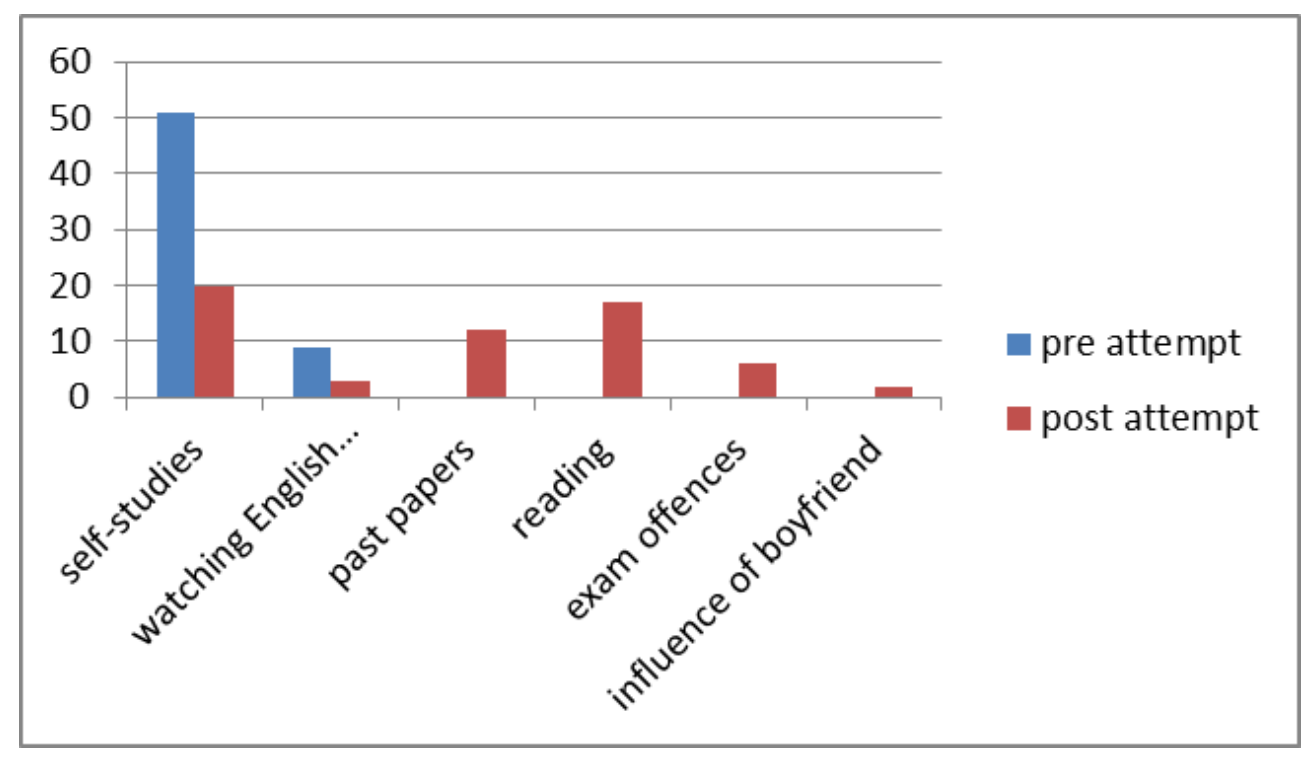

Figure 2: Evaluation of question number 02

The expansion of thoughts is fascinating that few students have developed their thinking patterns to imagine of the influence one could get from identical twins, exam offences and boyfriends. 2 options at the pre spot-test has increased up to 6 options at the post spot-test, marking a progress in thinking patterns.

For the third question which was emotional on saving only 1 family member from fire, the responses were as follows. One student avoided this question in the pre attempt, mentioning that it was too emotional for him to think of a solution. 15 students said it was mother they would save but that option declined to 8 in the post attempt. The 24 answers of saving sister, increased up to 32 in the post attempt. And the student who avoided writing an answer has also answered in the post attempt. The 2 reasons given by those who would save father were that after saving the father, they both could try to save the remaining three together and the fact men are physically stronger for a salvage activity. Reasons for saving mom were that there might be siblings outside the fire and they need a mother and the fact that they love their mother the most. Those who wanted to save grandmother said that she is too old even to make an attempt alone to escape and needs help. Majority opted to save sister as she is young, having many years ahead to live and should be protected because she represents the future generation of the country. 


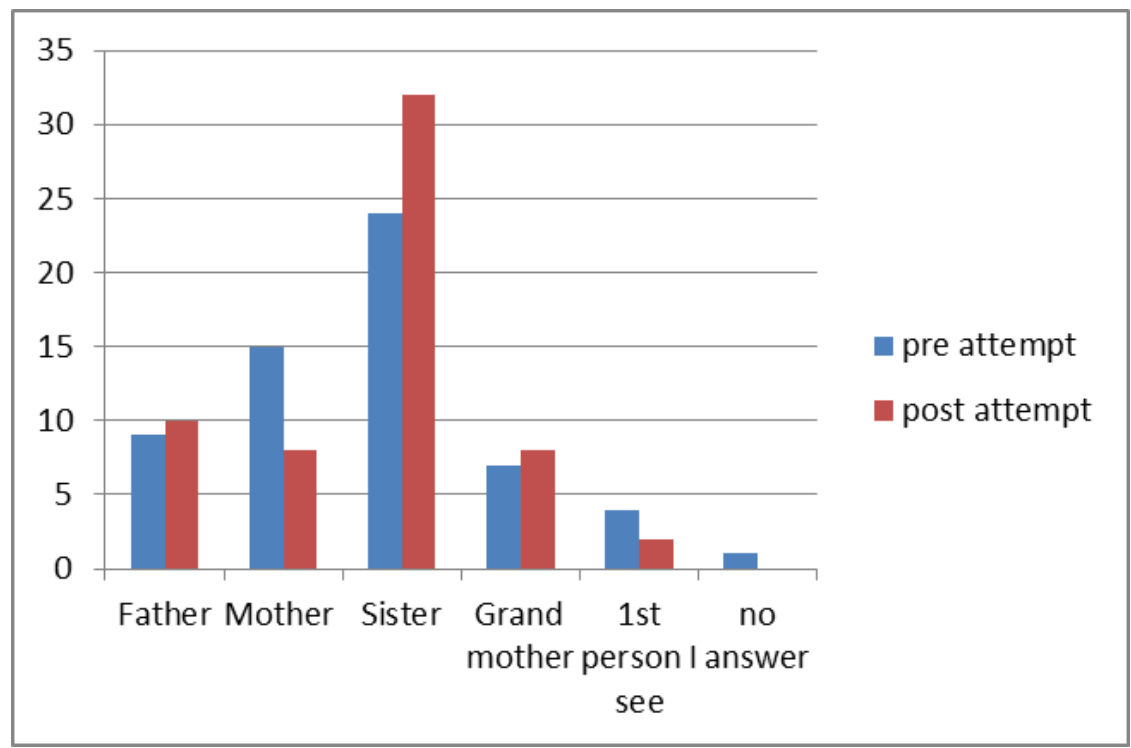

Figure 3: Evaluation of question number 03

This question was tricky but through that, the logical and analytical thinking abilities of the students were easily figured out. The emotional impact of students when taking decisions was evident through selection of grandmother and especially mother. It was also observed that the numbers have changed from emotional aspect to logical and analytical thinking aspects in selecting sister and father in the post attempt.

The last question, required the students to choose between 3 people; an old man, a friend and the dream girl. The results were evaluated as follows.

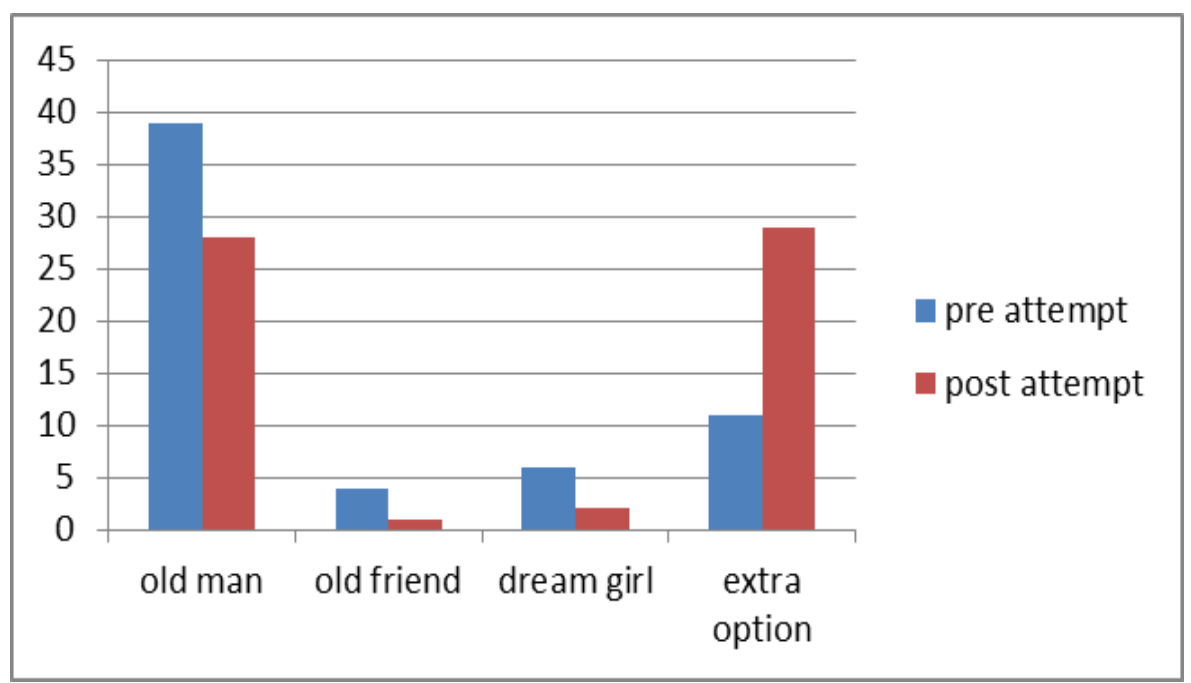

Figure 4: Evaluation of question number 04

The results depict the thinking ability of the students in taking critical decisions. The emotional impact of choosing the sick old man to be rushed into a hospital is prominent in the pre attempt, but an extra option has drastically increased in the post attempt. The extra option given and suggested by the students were that they would give the bike to the friend to take the sick old man to the hospital and that he would wait at the bus stop 
with the dream girl. The purpose of helping the old man and the friend together with taking the opportunity to impress the girl and ask her out will be fulfilled when this decision is taken.

Considering the interviews, every student said that the course was good and it is the best way to learn English. They told it was a novel experience for them and the course was energizing and fun-filled and that it was different to the other English language classes they had been. Every student claimed it was learning English through engaging in problems that they enjoyed the most, marking $100 \%$ student satisfaction of the teachinglearning process. In addition, 6 students said they enjoyed role plays because most of the role plays dealt with real-life situations. 2 students have liked the poster presentation session and the other 2 students were happy with every activity done in the class.

The population further pointed out that they preferred the special course to the regular English class, because the regular lecture was focusing on assignments, end-semester exam, grammar and they sit and learn as it is a teacher centered lecture. One of them told that they feel sleepy in studying grammar and doing traditional writing exercises. They have found the special course interesting due to the following reasons;

- students feel free to explore the language

- students could involve in discussing social and personal problems in a friendly confortable environment

- students enjoyed the sessions without academic stress since all the activities are activity based

- Activities provided them with an opportunity to debate their individual thoughts on a common platform. They could then, collaboratively arrive at effective solutions.

One student said they become curious before every lecture and guessed together with friends what the content (activities) would be for the day. Another student said he liked this out of his other lectures, because he could be influenced by the 'active part of English'. He liked the course because it enhanced many skills which are essential for an undergraduate.

The undergraduates liked learning through problems and told it is a better way and sometimes the best way to learn a language. According to one student they become 'real learners' as the language was acquired through involvement of their own issues. They told it is effective than the other methods as they get first hand involvement in the language. They liked the fact that the teacher also joined in some activities either as a part of the group or as a guide. One student told language teaching / learning, unlike learning science or math, has to be practical and real and should give more exposure to the language.

For the question, which skill they think they developed the most, 2 students told it was problem solving skills and 5 students told it was logical thinking and 3 said it was analytical thinking. 


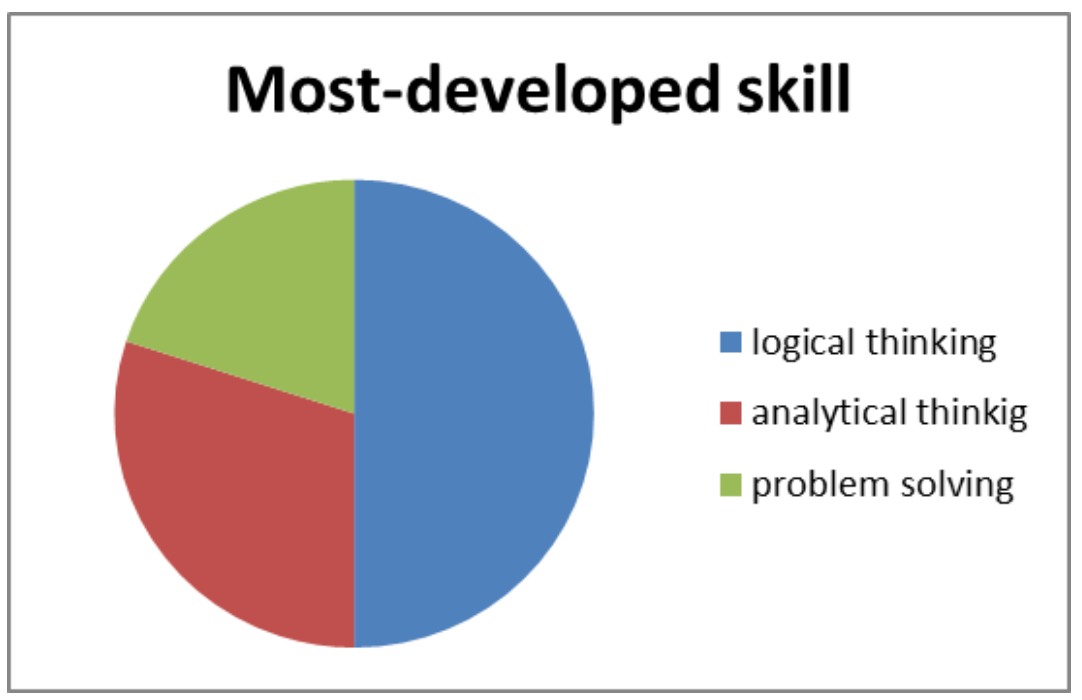

Figure 5: Evaluation of interviews 02

The students further pointed out assignments, $80 \%$ attendance rule and competition for a good Grade Average Point (GPA) were the factors which motivated them to attend regular lectures more than the need to seek new knowledge. Factors which de-motivated them were listed as their laziness to attend traditional and typical lectures, personal reasons like being sick, academic stress due to load of assignments and pressure from peers. One student revealed that they would rather play video games or play cards at the university cafeteria with friends than attending a lecture if they feel that the lecture is boring. However, these reasons are common to any lecture in the university, irrespective to the subject.

Considering research done on PBL in global level, Zareeha (2013) pointed out that in non-PBL approach, students involve in the process of listening, writing and giving direct single answers whereas PBL develops students' problem solving abilities. Santharooban \& Sathaananthan (2013), through a research done at the Eastern University of Sri Lanka, revealed that library usage of the undergraduates can be increased using PBL. Fernando \& Kumanayake (2014), researching on outcome based education through PBL, pointed out that PBL can enhance students' abilities in critical thinking, analysis and problem solving in practical scenarios.

\section{Findings and Conclusion}

It was impressive to note the development of thinking patterns of the students over a semester. They have begun to think in a different way, proving that PBL can develop thinking patterns of learners in a positive way. The answers were not discussed following the pre-attempt, nor were the students made aware that the same set of questions was to be posed at them at the end of the semester. The four questions did not carry particular or designed answers, but through the answers given, the thinking patterns, of the learners could be assessed. Hence it was proven that the analytical and logical thinking abilities of learners could be developed through problembased learning. Not only the two targeted skills, but also other cognitive skills such as critical thinking, justification skills, IQ abilities as well as language skills like reading, writing, speaking, listening together with grammar and vocabulary could also be developed through problem-based learning.

It was also proven that the students liked the special course better than the regular English class. Their eagerness to participate in the course was visible through the fact that they enjoyed guessing and predicting the content and type of activities for the day, before the session started. There was an average of $85-95 \%$ of attendance for each student. 
The student interviews proved that the students liked the activities conducted using PBL. Thus it was proven that PBL is a successful method in developing many skills of the learners. Thus the hypothesis, "logical and analytical thinking abilities of the undergraduates can be developed through PBL" was proven and it was found that PBL can play an effective role not only in enhancing logical thinking and analytical thinking skills, but many other language related soft skills as well.

\section{Suggestions}

Firstly, language development activities such as English club activities, Inter-faculty debates, Inter-university English competitions, English days and Language camps have to be implemented at university level in order to see enhancement of language and soft skill abilities. Secondly, problem based activities could be introduced into the language curriculum as the existing language curriculum doesn't incorporate any PBL components in them. Thirdly, universities should work on incorporating skill development sessions and language enhancement programmes at their orientation programmes to uplift skills-related student abilities. Lastly, as discussed in the research problem, English teaching should be facilitated at school level making English proficiency compulsory for university entrance. Through these suggestions, the students will have the ability to manage time in academic activities, as well as developing other soft skills.

\section{References}

Attanayake, A. (2010, March 13). English for learning other subjects in English. Daily News,

Barrows, H. S. \& Tamblyn, R. M. (1980). Problem-based learning: An approach to medical education. (Springer Publishing Company).

Clayton, G. \& Pierpoint, P. (1996). Problem Based Learning: A Would-be Practitioner's Guide. A National Teaching Fellowship Project 2001-0. University of Plymouth Business School.

Fernando, K. \& Kumanayake, R. (2014), Proceedings from The International Symposium on Expanding Development Horizons through Education, Research and Innovation 2014, Implementing Outcome Based Education through Problem Based Learning: A Case Study of Kotelawala Defence University, General Sir John Kotelawala Defence University, Sri Lanka.

Gunawardene, A. \& Karunaratne, B. (2017). Teacher Research: Remedy for Faliures in English Language Teaching in Sri Lanka. Retrieved from https://www.researchgate.net/publication/318901986.

Silver, H. \& Cindy, E. (2004), Educational Psychology Review, 16: 235. https://doi.org/10.1023/B:EDPR.0000034022.16470.f3

Hoffman, B. \& Ritchie, D. (1997), 'Using multimedia to overcome the problems with problem based learning', Instructional Science, 25, pp. 97-115. doi: 10.2307/23371480.

Kassem, M.A.M. (2018). Improving EFL Students' Speaking Proficiency and Motivation: A Hybrid Problembased Learning Approach, Theory and Practice in Language Studies. Vol. 8. No. 7, pp. 848-859, DOI: http://dx.doi.org/10.17507/tpls.0807.17

Lam, D. (2004), 'Problem-Based Learning: An Integration Of Theory And Field', Journal of Social Work Education, 40(3), pp. 371-389. doi: 10.2307/23043989.

Larsson, J. (2001). Problem-Based Learning: A possible approach to language education. Retrieved December, $10,2012$.

Modiano, M. (2011). Linguistic imperialism, cultural integrity, and EIL, ELT Journal, Volume 55, Issue 4, Pages 339-347, https://doi.org/10.1093/elt/55.4.339

Ngowananchai, J. (2013). Natural occurring conversation as an English teaching model in Thailand. European Scientific Journal.

Neo, M. \& Neo, K.T.K. (2001). Innovative teaching: Using multimedia in a problem-based learning environment, Journal of Educational Technology \& Society, 4(4), pp. 19-31. doi: 10.2307/jeductechsoci.4.4.19. 
Santharooban, S. \& Sathaananthan, T. (2013). Effect of Problem Based Learning (PBL) on Library Usage: a Study at Faculty of Health-Care Sciences, Eastern University of Sri Lanka. Journal of the University Librarians Association of Sri Lanka, 17 (1).

Zareeha, M. T. (2013). Use Of Problem-Based Learning To Teach Properties, Applications And Reactions Of Substances In Grade Nine (Doctoral dissertation).

https://www.insightassessment.com/Products/Products-Summary/Critical-Thinking-Skills-Tests/CaliforniaCritical-Thinking-Skills-Test-CCTST

www.thebalancecareers.com

www.quora.com 


\section{Appendix}

Table 1: Structure designed for PBL Lessons

\begin{tabular}{|c|c|c|c|c|c|c|}
\hline Lesson & Theme & Hours & $\begin{array}{l}\text { Main } \\
\text { Objectives }\end{array}$ & Sub Objectives & $\begin{array}{l}\text { Language } \\
\text { Skills }\end{array}$ & Other skills \\
\hline $01 \mathrm{PBL}$ & $\begin{array}{l}\text { Understanding } \\
\text { a Problem }\end{array}$ & 3 & \multirow{5}{*}{$\begin{array}{l}\text { - To find out if } \\
\text { critical thinking } \\
\text { ability could be } \\
\text { developed } \\
\text { through PBL } \\
\text { - To find out if } \\
\text { logical thinking } \\
\text { ability could be } \\
\text { developed } \\
\text { through PBL } \\
\text { To be achieved } \\
\text { at the end of the } \\
\text { interview, } \\
\text { - To analyze } \\
\text { the } \\
\text { effectiveness of } \\
\text { PBL in English } \\
\text { Language } \\
\text { Teaching } \\
\text { To be achieved } \\
\text { by the } \\
\text { questionnaire, } \\
\text { - To find out } \\
\text { whether PBL } \\
\text { can be useful to } \\
\text { retain students } \\
\text { in the ESL } \\
\text { classroom } \\
\text { ang }\end{array}$} & $\begin{array}{l}\text { - To find out } \\
\text { the day-to-day } \\
\text { problems } \\
\text { people have } \\
\text { - To } \\
\text { understand the } \\
\text { types of } \\
\text { problems }\end{array}$ & $\begin{array}{l}\text { Listening } \\
\text { Reading } \\
\text { Speaking }\end{array}$ & $\begin{array}{l}\text { Critical } \\
\text { thinking }\end{array}$ \\
\hline $03 \mathrm{PBL}$ & $\begin{array}{l}\text { Identifying } \\
\text { key issues of a } \\
\text { Problem }\end{array}$ & 3 & & $\begin{array}{l}\text { - To identify } \\
\text { and list down } \\
\text { the key issues } \\
\text { of a problem } \\
\text { given } \\
\text { - To categorize } \\
\text { those issues in } \\
\text { order to gain a } \\
\text { deeper } \\
\text { understanding } \\
\text { of the problem }\end{array}$ & $\begin{array}{l}\text { Reading } \\
\text { Writing } \\
\text { Grammar }\end{array}$ & $\begin{array}{l}\text { Logical } \\
\text { thinking }\end{array}$ \\
\hline $05 \mathrm{PBL}$ & $\begin{array}{l}\text { Analyzing a } \\
\text { Problem }\end{array}$ & 6 & & $\begin{array}{l}\text { - To find out } \\
\text { the root causes } \\
\text { of problems } \\
\text { - To discover } \\
\text { complex } \\
\text { systems around } \\
\text { problems } \\
\text { - To identify } \\
\text { key points of } \\
\text { failure in a } \\
\text { problem }\end{array}$ & $\begin{array}{l}\text { Listening } \\
\text { Writing } \\
\text { Speaking }\end{array}$ & $\begin{array}{l}\text { Analytical } \\
\text { skills }\end{array}$ \\
\hline $07 \mathrm{PBL}$ & $\begin{array}{l}\text { Generating } \\
\text { Possible } \\
\text { Explanations }\end{array}$ & 3 & & $\begin{array}{l}\text { - To produce } \\
\text { probable } \\
\text { interpretations } \\
\text { to a set of } \\
\text { issues given } \\
\text { - To list down } \\
\text { the reasons for } \\
\text { problem } \\
\text { causing }\end{array}$ & $\begin{array}{l}\text { Listening } \\
\text { Speaking } \\
\text { Grammar }\end{array}$ & $\begin{array}{l}\text { Justification } \\
\text { skills }\end{array}$ \\
\hline $09 \mathrm{PBL}$ & $\begin{array}{l}\text { Integrating } \\
\text { New Concepts }\end{array}$ & 3 & & $\begin{array}{l}\text { - To make a } \\
\text { practical } \\
\text { connection } \\
\text { between the } \\
\text { 'student } \\
\text { problems' and }\end{array}$ & $\begin{array}{l}\text { Reading } \\
\text { Writing } \\
\text { Speaking }\end{array}$ & $\begin{array}{l}\text { Independent } \\
\text { thinking }\end{array}$ \\
\hline
\end{tabular}




\begin{tabular}{|c|c|c|c|c|}
\hline & & $\begin{array}{l}\text { 'real world } \\
\text { situations' } \\
\text { - To use } \\
\text { 'student } \\
\text { problems' to } \\
\text { motivate, focus } \\
\text { and initiate } \\
\text { student } \\
\text { learning }\end{array}$ & & \\
\hline $11 \mathrm{PBL}$ & $\begin{array}{l}\text { Taking } \\
\text { Decisions and } \\
\text { Solving } \\
\text { Problems }\end{array}$ & $\begin{array}{l}\text { - To solve } \\
\text { individual } \\
\text { problems } \\
\text { through } \\
\text { discussions and } \\
\text { explore } \\
\text { relationship } \\
\text { problems } \\
\text { - To improve } \\
\text { analytical skills } \\
\text { by making } \\
\text { incomplete } \\
\text { problems } \\
\text { comprehensive, } \\
\text { tailoring it } \\
\text { together with } \\
\text { the English } \\
\text { language } \\
\text { - To take } \\
\text { decisions and } \\
\text { come into } \\
\text { conclusions } \\
\text { while } \\
\text { enhancing } \\
\text { interactive } \\
\text { skills. }\end{array}$ & $\begin{array}{l}\text { Listening } \\
\text { Speaking } \\
\text { Grammar }\end{array}$ & $\begin{array}{l}\text { Problem } \\
\text { solving } \\
\text { skills }\end{array}$ \\
\hline
\end{tabular}

